\title{
Jakość relacji z przełożonymi jako czynnik determinujący zaangażowanie pracowników (na przykładzie uczelni wyższej)
}

\author{
Sylwia Stachowska \\ Katedra Organizacji i Zarządzania, Wydział Nauk Ekonomicznych, \\ Uniwersytet Warmińsko-Mazurski w Olsztynie
}

\begin{abstract}
We współczesnych uwarunkowaniach problematyka dotycząca kształtowania zaangażowania pracowników, będącego czynnikiem o kluczowym znaczeniu dla osiągania celów organizacji, a zarazem wyznacznikiem skuteczności zarządzania kapitałem ludzkim, jest ważna z punktu widzenia każdej organizacji, w tym również uczelni wyższych. W procesie budowania zaangażowania pracowników istotną rolę odgrywa identyfikacja znaczenia różnorodnych czynników determinujących jego poziom. Jednym z takich czynników jest jakość relacji z bezpośrednimi przełożonymi. Podstawowym celem badania prezentowanego w niniejszym artykułu była identyfikacja znaczenia jakości relacji z przełożonymi jako jednego z czynników kształtujących zaangażowanie pracowników Uniwersytetu Warmińsko-Mazurskiego w Olsztynie. Badanie służące realizacji celu zostało przeprowadzone metodą ankietową wśród nauczycieli akademickich oraz osób niebędących nauczycielami akademickimi.
\end{abstract}

Słowa kluczowe: zaangażowanie pracowników, czynniki kształtujące zaangażowanie pracowników, relacje z przełożonymi, zarządzanie kapitałem ludzkim

\section{Wprowadzenie}

W uwarunkowaniach wysokiej konkurencyjności, rozwoju gospodarki opartej na wiedzy oraz dynamicznych zmian zachodzących w otoczeniu, wpływających na funkcjonowanie współczesnych organizacji, w tym również zmian pokoleniowych w strukturze zatrudnienia, rośnie znaczenie zaangażowania jako cechy pracowników stanowiącej istotną determinantę wykorzystania ich potencjału, kluczowego 
czynnika sprzyjającego osiąganiu celów organizacyjnych, a także przywiązaniu pracowników do organizacji i integrowaniu się z nią. Organizacje stają wobec wyzwania polegającego na stworzeniu i odpowiednim wykorzystaniu zestawu czynników, mającego na celu zapewnienie wysokiego poziomu zaangażowania zatrudnionych osób, który z kolei jest uznawany także za istotny miernik skuteczności zarządzania kapitałem ludzkim (Juchnowicz, 2010, s. 57).

Problematyka dotycząca zaangażowania jest istotna z punktu widzenia funkcjonowania każdej organizacji, nie omija również funkcjonujących na rynku uczelni wyższych. W uczelniach, w których jakość realizowanych zadań w dużym stopniu zależy od zaangażowania zatrudnionych osób (co dotyczy zarówno nauczycieli akademickich, jak i pracowników niebędących nauczycielami akademickimi), wyzwaniem staje się osiągnięcie odpowiedniego poziomu motywacji i zaangażowania. Posiadanie nawet najlepiej wykwalifikowanych pracowników nie musi się bowiem przekładać na wyższą efektywność. Zaangażowanie jest kluczem do tego, aby potencjał pracowników przełożyć na efekty pracy. Ma ono swoje źródło nie tylko w gratyfikacjach finansowych, lecz także w postrzeganiu swoich możliwości rozwoju adekwatnie do indywidualnych oczekiwań czy w pozytywnym nastawieniu do organizacji, współpracowników i przełożonych.

Dla poprawy jakości funkcjonowania uczelni, wzrostu efektywności, kreatywności i inicjatywy pracowników niezbędne są działania w zakresie podnoszenia jakości zarządzania zasobami ludzkimi, zwiększania stopnia identyfikacji z organizacją, podwyższania zaangażowania, zadowolenia z pracy i wzrostu motywacji. Z punktu widzenia ich skuteczności ważne jest poznanie znaczenia różnorodnych czynników wpływających na poziom zaangażowania pracowników, co pozwoli na wyciągnięcie wniosków dotyczących optymalnych działań w zakresie zarządzania kapitałem ludzkim. Jednym z takich czynników są relacje z bezpośrednimi przełożonymi.

Podstawowym celem badania prezentowanego w niniejszym artykule była identyfikacja znaczenia jakości relacji z przełożonymi jako jednego z czynników kształtujących zaangażowanie pracowników Uniwersytetu Warmińsko-Mazurskiego w Olsztynie. Badanie służące realizacji tego celu zostało przeprowadzone metodą ankietową w grupie nauczycieli akademickich oraz osób niebędących nauczycielami akademickimi.

\section{Pojęcie i istota zaangażowania organizacyjnego}

Termin „zaangażowanie”, choć używany w zarządzaniu od wielu lat, jest przykładem pojęcia niejednoznacznego, stosowanego w różnych kontekstach znaczeniowych. Bywa utożsamiane ze stanem, postawą, atrybutem postawy czy też zespołem zachowań. Trudność sprawia również wyznaczenie granic czy związków 
między zaangażowaniem pracowników a takimi pojęciami, jak lojalność, przywiązanie, satysfakcja z pracy, motywacja wewnętrzna lub relacje z organizacją. Jest ono często kojarzone również z takimi pojęciami, jak pasja czy entuzjazm. To wszystko decyduje o tym, że pojęcie zaangażowania pracowników (employee engagement) jest trudne do zdefiniowania i zarówno na gruncie rozważań teoretycznych, jak i w praktyce gospodarczej może się kryć pod nim wiele różnych znaczeń.

Podejścia dotyczące zaangażowania organizacyjnego można pogrupować w trzy podstawowe obszary (Spik, Klincewicz, 2008, s. 477):

1) zaangażowanie jako emocjonalne przywiązanie (zaangażowanie emocjonalne, afektywne), którego charakterystyczną cechą jest to, że osoby o jego wysokim poziomie utożsamiają się z organizacją, angażują się w nią oraz są zadowolone z bycia jej uczestnikami;

2) zaangażowanie jako wynik postrzeganych kosztów opuszczenia organizacji (określane jako „poznawcze zaangażowanie trwania”), które pojawia się, gdy kontynuowanie uczestnictwa w organizacji jest związane z korzyściami, a odejście - z kosztami (stratami);

3) zaangażowanie jako obowiązek, związane z przekonaniem uczestnika organizacji o zobligowaniu w stosunku do niej, traktowane jako normatywna presja na działanie zgodnie $\mathrm{z}$ jej celami.

W literaturze przedmiotu można także wyróżnić trzy różne koncepcje dotyczące istoty zaangażowania (Burkiewicz, 2003, s. 58): 1) zaangażowanie jako rodzaj postawy, 2) zaangażowanie behawioralne (wyrażające się określonym zachowaniem) oraz 3) zaangażowanie oparte na wzajemnej wymianie świadczeń między pracownikiem a organizacją.

Zaangażowanie jest określane jako przywiązanie pracowników do organizacji oraz pełnionych przez nich ról (Kahn, 1990, s. 694). Model zaangażowania organizacyjnego, w którym jest ono utożsamiane z postawą pracownika opartą na identyfikacji z organizacją i przywiązaniem do niej, przedstawia je w trzech aspektach: 1) racjonalnym (np. rozumienie i wspieranie celów organizacji), 2) emocjonalnym (np. poczucie dumy z faktu przynależności do organizacji) i 3) behawioralnym (np. podejmowanie dodatkowego wysiłku na rzecz organizacji) (Meyer, Allen, 1991, s. 61-89). Zaangażowany pracownik to taki, który ma silne pragnienie, aby pozostać członkiem danej organizacji, jest skłonny do wysokiego poziomu wysiłku na jej rzecz, wierzy w cele i wartości swojej organizacji (Cohen, 2007, s. 338). Spotykane w literaturze definicje zaangażowania często odnoszą to pojęcie do emocjonalnego i intelektualnego przywiązania do organizacji oraz sumy wysiłku, jaki pracownik decyduje się włożyć w realizację swoich obowiązków (Kinowska, 2009, s. 66).

Zaangażowanie jest również określane jako utrzymujący się poznawczo-afektywny stan umysłu dający poczucie spełnienia, którego charakteryzuje wigor 
(wysoki poziom energii, wysiłek wkładany w pracę), poświęcenie (oddanie, entuzjazm w pracy) i absorpcja (pochłonięcie, koncentracja na pracy) (Schaufeli i in., 2002, s. 74). P. Falcone (2006) określa zaangażowanie jako stan emocjonalnego i intelektualnego oddania (commitment) organizacji. Według tego autora, zaangażowany pracownik jest osobą w pełni oddaną (involved) swojej pracy i entuzjastyczną w stosunku do niej. Zdaniem M. Armstronga (2009, s. 123), o zaangażowaniu można mówić wówczas, gdy pracownicy są szczerze zainteresowani i zaabsorbowani swoją pracą, a nawet pasjonują się nią, co skłania ich do podejmowania dobrowolnych wysiłków przekraczających formalne obowiązki.

Można powiedzieć, że zaangażowanie to specyficzne, względnie trwałe zachowanie się w określony sposób wobec przedmiotu postawy, którym może być organizacja, zawód, wykonywana praca, a także środowisko społeczne, w którym pracownik funkcjonuje (Juchnowicz, 2012, s. 35). Zaangażowanie pracownika może się więc przejawiać w czterech formach (Bugdol, 2006, s. 86):

1) zaangażowanie w organizację, czyli identyfikacja z jej misją, wspólnymi wartościami, a także z celami i zadaniami,

2) zaangażowanie w pracę, czyli w wykonywanie codziennych zadań na wysokim poziomie,

3) zaangażowanie w zawód (profesję), polegające na silnej identyfikacji z indywidualnymi celami rozwoju zawodowego oraz konsekwentnej realizacji własnej ścieżki kariery,

4) zaangażowanie w środowisko społeczne, określone przez identyfikację z przełożonymi i współpracownikami.

Zaangażowanie w pracę czy wykonywany zawód jest warunkiem niezbędnym, ale niewystarczającym do zaangażowania organizacyjnego, które oznacza identyfikację z celami i wartościami organizacji, pragnienie przynależności oraz gotowość do działania, nadającą wysoką rangę interesom organizacji, a nawet priorytet nad własnymi interesami jednostki (Juchnowicz, 2009, s. 17).

O ile samo pojęcie zaangażowania jest trudne do zdefiniowania, o tyle wątpliwości nie budzi raczej jednak fakt, iż zaangażowanie pracowników ma kluczowe znaczenie dla osiągania celów organizacji. Zaangażowanie sprzyja przywiązaniu pracownika do organizacji, integrowaniu się z nią. Budowa zaangażowania ma więc kluczowe znaczenie w zarządzaniu kapitałem ludzkim oraz rozwoju organizacji. Przemawiają za tym m.in. następujące argumenty (Borkowska, 2014, s. 10-11):

- pracownicy zaangażowani w pracę lub organizację identyfikują się z nią i łączą $\mathrm{z}$ nią swoje życie zawodowe,

- wśród pracowników zaangażowanych absencja i płynność kadr są mniejsze,

- zaangażowanie pracowników pozytywnie wpływa na jakość ich pracy, a także na stosunki międzyludzkie w organizacji, 
- zaangażowani pracownicy wywierają pozytywny wpływ na przetrwanie i rozwój organizacji oraz jej pozycję rynkową,

- zaangażowanie pracowników wzmacnia pozycję samego zarządzania kapitałem ludzkim, którego jest integralnym subobszarem,

- zaangażowanie przynosi korzyści także samym pracownikom, do których należą: satysfakcja ze swoich dokonań, zazwyczaj większe uznanie oraz większa skłonność do inwestowania w ich rozwój ze strony pracodawcy.

Poziom i rodzaj wpływu wymienionych czynników na zarządzanie kapitałem ludzkim zależą od rodzaju zaangażowania oraz jego poziomu. Wiąże się to z potrzebą, a nawet koniecznością wzmacniania zaangażowania pracowników poprzez odpowiednie ich motywowanie.

\section{Czynniki kształtujące zaangażowanie pracowników}

Zaangażowanie pracowników, będące efektem procesu kształtowania postaw i zachowań w organizacji, jest celem podejmowanych w organizacji działań motywacyjnych, a zarazem dowodem i miarą ich skuteczności ${ }^{1}$. Osiągnięcie wysokiego poziomu zaangażowania wymaga identyfikacji pracowników z organizacją. Aby to osiągnąć, należy kształtować stosunki pracy oparte na stabilizacji, wspólnej odpowiedzialności i partycypacji decyzyjnej. Inspirowanie do wysokiego poziomu zaangażowania wymaga odwołania się do szerokiego spektrum potrzeb, celów zawodowych i osobistych pracowników, co oznacza potrzebę uruchomienia wielu instrumentów motywacyjnych. Etapem wstępnym jest zastosowanie odpowiednich nagród zewnętrznych, do których można zaliczyć wynagrodzenia finansowe, warunki pracy, pozycję w hierarchii organizacyjnej oraz pewność zatrudnienia. Efektywne nagrody zewnętrzne są warunkiem niezbędnym, ale jednak niewystarczającym do osiągnięcia pełnego zaangażowania. Niezbędne jest uzupełnienie ich kompleksem nagród wewnętrznych, takich jak możliwości rozwoju, samodzielność, wyrażanie uznania itp.

W literaturze przedmiotu wskazuje się wiele warunków, jakie należy spełnić, aby zbudować zaangażowanie pracowników. Według P. Burnsa (2005, s. 214), wymaga to rewitalizacji firmy poprzez podejmowanie ogólnoorganizacyjnych działań strategicznych, budowanie nowej kultury organizacyjnej, wdrażanie nowych wartości, budowanie efektywnych systemów komunikacji i motywowanie

1 M. Armstrong (2009, s. 125) wskazuje na różnice między motywacją a zaangażowaniem, stwierdzając, że motywacja dotyczy chęci podejmowania działania, a nie postawy pracownika. Motywacja nie musi więc być jednoznaczna z zaangażowaniem. 
oraz stworzenie struktur inicjatyw pracowniczych. T.A. Kochan i L. Dyer (1993, s. 569-590) czynniki kształtujące zaangażowanie podzielili na trzy poziomy:

1) strategiczny - obejmujący strategię i wartości organizacji,

2) funkcjonalny - związany z realizacją polityki zarządzania zasobami ludzkimi (w tym szkolenia, wynagrodzenia itp.),

3) dotyczący miejsca pracy - odpowiedni dobór pracowników, szeroko zakrojone zadania, praca zespołowa, udział w rozwiązywaniu problemów, atmosfera współpracy i zaufania.

D. Robinson, S. Perryman i S. Hayday (2004, s. 23) stworzyli listę czynników zaangażowania, wśród których znalazły się: szkolenia, rozwój i kariera, system ocen i wyników, komunikowanie się oraz zadowolenie z pracy, a także relacje z bezpośrednimi przełożonymi, równe możliwości i sprawiedliwe traktowanie, płaca i świadczenia, zdrowie i bezpieczeństwo, współpraca oraz przyjazne stosunki międzyludzkie. Wiele badań potwierdza również, że głównymi czynnikami zaangażowania są poczucie bycia docenianym i uczestnictwo (Smythe, 2009, s. 236). Warunki efektywnego zaangażowania można także przedstawić w postaci dziewięciu podstawowych czynników (Croston, 2008, s. 166): 1) zachowania przywódcze wyższej kadry zarządzającej, 2) relacje z bezpośrednim przełożonym, 3) interesująca, stawiająca wyzwania praca, 4) perspektywy rozwoju, 5) udział w podejmowaniu decyzji, 6) samodzielność działania, 7) zespołowa kultura organizacyjna, 8) dobra komunikacja wewnętrzna oraz 9) odpowiednie warunki pracy, wspierające systemy i struktury. Na liście tej dominują czynniki typowe dla koncepcji zarządzania zasobami ludzkimi, które można uznać za bazę zaangażowania pracowników, zaś nadbudowę stanowią struktura organizacji, wsparcie i jakość przywództwa.

J. Smythe (2009, s. 53) opiera zaangażowanie pracowników na procesie decyzyjnym, wśród czynników je kształtujących wymieniając m.in. przywództwo, system komunikowania się, szkolenia i podnoszenie kwalifikacji zawodowych. Jako determinanty zaangażowania są również wskazywane: środowisko pracy, przywództwo, praca zespołowa i współpraca, szkolenia i rozwój kariery, wynagrodzenie, polityka organizacji, poczucie jakości życia w pracy (Anitha, 2014, s. 311). M. Armstrong, w swoich rozważaniach na temat zaangażowania pracowników, nawiązuje zaś do modelu Hay Group, w którym jego determinantami są (Armstrong, 2007, s. 231-232):

- inspiracje i wartości - reputacja organizacji, postawy i zachowania, jakość przywództwa, uznanie i komunikacja,

- jakość pracy - sposób postrzegania wartości pracy, wyzwania, zainteresowania, autonomia, możliwość zrobienia czegoś ważnego, jakość stosunków pracowniczych,

- korzystne środowisko pracy - otoczenie fizyczne, dostępne narzędzia i wyposażenie, szkolenia, informacja i procesy, bezpieczeństwo w pracy, 
- nagrody materialne - konkurencyjna płaca, atrakcyjny system świadczeń, nagrody za wyniki, możliwość uzyskania prawa własności, sprawiedliwy system nagradzania,

- równowaga między pracą a życiem osobistym - wspierające środowisko pracy, dostrzeganie potrzeb związanych z życiem prywatnym pracownika, bezpieczeństwo dochodów i wsparcie socjalne,

- możliwości rozwoju zawodowego - szkolenia, awans zawodowy, informacje zwrotne.

$\mathrm{Na}$ uwagę zasługuje stworzony na potrzeby badań na gruncie polskim autorski model zaangażowania pracowników w organizacji (WIGOR), zaproponowany przez M. Juchnowicz (2010, s. 58-60), w którym określono pięć grup czynników determinujących poziom zaangażowania pracowników w organizacji. Zaliczone do nich zostały: organizacja pracy, możliwości rozwoju, zasady i mechanizmy wynagradzania, stosunki ze współpracownikami oraz relacje $z$ bezpośrednim przełożonym.

W literaturze przedmiotu są również przytaczane listy czynników wpływających na zaangażowanie pracowników stworzone przez firmy konsultingowe zajmujące się badaniem poziomu zaangażowania w organizacjach. Wśród nich na uwagę zasługuje model opracowany przez firmę Mercer, złożony z trzynastu bloków czynników, do których zaliczono: procesy pracy, zarządzanie wynikami, pewność pracy i rozwój kariery, jakość i koncentracja na konsumentach, wynagrodzenie, korzyści, praca w grupie i kooperacja, przywództwo, komunikacja, szkolenia i rozwój, etyka i integracja, bezpośredni przełożony, równowaga między życiem osobistym a życiem zawodowym (Gajdzik, 2012, s. 76).

Dokonany na potrzeby niniejszego artykułu przegląd literatury niewątpliwie nie wyczerpuje analizy problematyki dotyczącej zaangażowania pracowników z punktu widzenia czynników je kształtujących. Wynika z niego jednak, że jednym z czynników odgrywających ważną rolę w tej kwestii są relacje z przełożonymi. To właśnie bezpośredni przełożony - menedżer realizujący rolę przywódcy - jest kluczową postacią w procesie motywowania pracowników i budowy ich zaangażowania. To jego postawa, zachowanie, metody zarządzania, otwartość na problemy nie tylko organizacji, lecz także pracowników, decydują o kształcie procesu zarządzania. To on jest kluczową postacią w procesie budowania zespołu, dbałości o atmosferę pracy i relacje międzyludzkie.

Istotne znaczenie wzajemnych relacji pracowników z przełożonymi podkreśla m.in. M. Armstrong (2007, s. 227-228), wskazując pięć elementów składających się na strategię zaangażowania:

1) poczucie współwłasności - koncepcja ta zakłada włączanie pracowników w podejmowanie decyzji, aby dać im możliwość kreowania (przynajmniej w pewnym stopniu) swojego miejsca pracy; powinni mieć oni poczucie, że ich 
pomysły zostały wysłuchane i uwzględnione w ostatecznych decyzjach, zwiększa to bowiem prawdopodobieństwo akceptacji wprowadzanych zmian bądź narzucanych zadań;

2) efektywna komunikacja - zaangażowanie pracowników jest większe wówczas, gdy zachodzi efektywna komunikacja między nimi a kierownictwem; pracownicy powinni dokładnie rozumieć to, czego się od nich oczekuje i w co powinni się zaangażować;

3) jakość przywództwa - zaangażowanie wzrasta wtedy, kiedy menedżerowie potrafią zdobyć zaufanie i szacunek pracowników, z którymi pracują; sami także powinni wykazywać wysoki stopień zaangażowania, aby dawać dobry przykład podwładnym;

4) zadowolenie $z$ pracy - zwiększanie zadowolenia z pracy, a tym samym poziomu zaangażowania, koncentrując się na takich wewnętrznych czynnikach motywacji, jak: odpowiedzialność, osiągnięcia czy uznanie; zadowoleniu z pracy będzie m.in. sprzyjać poszerzanie przestrzeni pozwalającej pracownikom na wykorzystanie swoich umiejętności i zdolności, np. przez delegowanie uprawnień;

5) praktyki personalne zwiększające zaangażowanie - szkolenia, planowanie kariery, projektowanie stanowisk pracy, zarządzanie przez efekty, zachowanie równowagi między życiem prywatnym a życiem zawodowym.

Biorąc pod uwagę znaczenie poruszanej problematyki, można powiedzieć, że jednym z ważniejszych wyzwań stojących obecnie przed osobami kierującymi zespołami pracowniczymi w organizacjach jest skuteczne wyzwalanie zaangażowania pracowników poprzez uruchomienie całego spektrum oddziaływań motywacyjnych, ze szczególnym uwzględnieniem jakości relacji kształtowanych na linii przełożony-podwładny.

\section{Próba identyfikacja znaczenia jakości relacji z przełożonymi jako jednego z czynników kształtujących zaangażowanie pracowników Uniwersytetu Warmińsko-Mazurskiego w Olsztynie}

\section{Cel i metodyka badania}

Celem przeprowadzonego badania była identyfikacja znaczenia jakości relacji z przełożonymi jako jednego z czynników kształtujących zaangażowanie pracowników Uniwersytetu Warmińsko-Mazurskiego w Olsztynie (w grupie nauczycieli 
akademickich - NA oraz osób niebędących nauczycielami akademickimi - NNA)². Badania służące realizacji celu zostały przeprowadzone metodą ankietową w 2016 r. Do analizy przyjęto 504 kwestionariusze ankiet w grupie nauczycieli akademickich (co stanowiło 26,1\% całkowitej liczby osób zatrudnionych w takim charakterze w uczelni) oraz 553 kwestionariusze w grupie pracowników niebędących nauczycielami akademickimi (co stanowiło 40,3\% zatrudnienia w analizowanej kategorii).

Wśród objętych badaniem nauczycieli akademickich przeważali mężczyźni ( $54,2 \%$ badanej populacji), natomiast w grupie pracowników niebędących nauczycielami akademickimi zdecydowanie dominowały kobiety (71,6\%). Najczęściej reprezentowaną kategorią wiekową, zarówno w pierwszej (NA - 51,8\%), jak i drugiej (NNA - 46,3\%) analizowanej grupie respondentów był przedział od 34 do 49 lat, drugą co do liczebności grupę stanowili pracownicy mający powyżej 50 lat (NA - 34,9\% oraz NNA - 32,4\%). Ponad połowa $(53,4 \%)$ badanych osób w grupie nauczycieli akademickich legitymowała się stażem pracy w uczelni powyżej 15 lat, natomiast w kategorii osób niebędących nauczycielami akademickimi większość $(60,4 \%)$ stanowili pracownicy ze stażem pracy do 15 lat.

Najliczniej reprezentowaną grupą w kategorii nauczycieli akademickich byli pracownicy naukowo-dydaktyczni $(79,2 \%)$ ze stopniem naukowym doktora (52,8\%), zatrudnieni na stanowisku adiunkta (50,8\%), natomiast w grupie osób niebędących nauczycielami akademickimi - pracownicy administracji $(50,8 \%)$. Zarówno w pierwszej (NA - 80,8\%), jak i w drugiej grupie (NNA - 89\%) dominowały osoby niezajmujące stanowisk kierowniczych.

\section{Wyniki badania}

Za najcenniejszy wśród czynników motywacyjnych wpływających na zaangażowanie pracowników respondenci uznali poziom otrzymywanego wynagrodzenia, ze zbliżonym odsetkiem wskazań w obydwu wyodrębnionych grupach (NA

2 Prezentowane badanie stanowi część znacznie szerzej zakrojonych badań ankietowych, których głównym celem była identyfikacja opinii pracowników Uniwersytetu Warmińsko-Mazurskiego w Olsztynie na temat obecnego systemu zarządzania zasobami ludzkimi w uczelni oraz ich oczekiwań w zakresie systemu motywowania, przeprowadzonych w ramach prac powołanego przez Rektora Zespołu ds. doskonalenia systemu zarządzania zasobami ludzkimi w uczelni, którego kierownikiem jest autorka niniejszego artykułu. W ramach przeprowadzonych badań zebrano m.in. opinie pracowników w kilku wyodrębnionych obszarach, wśród których, oprócz relacji z przełożonymi, znalazły się: uczenie się i rozwój, komunikacja i współpraca, organizacja pracy, wynagradzanie i motywowanie oraz stosunek do pracy i organizacji. W badaniach przyjęto założenie, że obszary te mają podstawowe znaczenie w budowaniu zaangażowania pracowników, a tym samym stanowią podstawę pomyślnego rozwoju uczelni. 
- 68,5\% oraz NNA - 68,2\%; tabele 1 i 2). Jakość relacji z przełożonymi znalazła się na piątym miejscu w hierarchii ważności motywatorów zarówno w grupie nauczycieli akademickich, jak i osób niebędących nauczycielami akademickimi, przy czym była częściej wskazywana w drugiej z wymienionych grup (NNA - 52,3\% odpowiedzi, a $N A-45,8 \%$ odpowiedzi).

Tabela 1. Najcenniejsze czynniki motywacyjne w opinii badanych nauczycieli akademickich

\begin{tabular}{|l|c|}
\hline \multicolumn{1}{|c|}{ Wyszczególnienie } & $\begin{array}{c}\text { Odpowiedzi } \\
\text { (w \%) }\end{array}$ \\
\hline Poziom otrzymywanego wynagrodzenia & 68,5 \\
\hline Stałość i bezpieczeństwo zatrudnienia & 53,6 \\
\hline Nagroda finansowa, podwyżka, premia & 49,2 \\
\hline Atmosfera pracy, relacje ze współpracownikami & 49,2 \\
\hline Dogodne godziny pracy (elastyczny czas pracy) & 48,6 \\
\hline Jakość relacji z przełożonymi & 45,8 \\
\hline Możliwość samodzielnego działania & 44,4 \\
\hline $\begin{array}{l}\text { Warunki pracy (wyposażenie stanowiska i dostępność do potrzebnych } \\
\text { zasobów) }\end{array}$ & 42,9 \\
\hline Możliwość podnoszenia kwalifikacji i rozwoju zawodowego & 37,7 \\
\hline Możliwość samorealizacji w pracy & 37,7 \\
\hline Jasne kryteria oceny pracy i awansu & 31,7 \\
\hline Prestiż stanowiska i miejsca pracy & 27,6 \\
\hline Organizacja pracy & 25,4 \\
\hline $\begin{array}{l}\text { Uznanie pozafinansowe od przełożonych (pochwała, dyplom, list } \\
\text { gratulacyjny itp.) }\end{array}$ & 24,4 \\
\hline $\begin{array}{l}\text { Dodatkowe świadczenia pozapłacowe (np. bony towarowe, dofinansowanie } \\
\text { wypoczynku, bilety na imprezy kulturalne) }\end{array}$ & 18,3 \\
\hline Żón & \\
\hline
\end{tabular}

Źródło: opracowanie własne na podstawie wyników przeprowadzonego badania ankietowego.

Tabela 2. Najcenniejsze czynniki motywacyjne w opinii badanych osób niebędących nauczycielami akademickimi

\begin{tabular}{|l|c|}
\hline \multicolumn{1}{|c|}{ Wyszczególnienie } & $\begin{array}{c}\text { Odpowiedzi } \\
(\mathrm{w} \%)\end{array}$ \\
\hline Poziom otrzymywanego wynagrodzenia & 68,2 \\
\hline Nagroda finansowa, podwyżka, premia & 67,8 \\
\hline
\end{tabular}




\begin{tabular}{|l|c|}
\hline \multicolumn{1}{|c|}{ Wyszczególnienie } & $\begin{array}{c}\text { Odpowiedzi } \\
\text { (w \%) }\end{array}$ \\
\hline Atmosfera pracy, relacje ze współpracownikami & 66,5 \\
\hline Stałość i bezpieczeństwo zatrudnienia & 65,6 \\
\hline Jakość relacji z przełożonymi & 52,3 \\
\hline Możliwość podnoszenia kwalifikacji i rozwoju zawodowego & 41,9 \\
\hline $\begin{array}{l}\text { Dodatkowe świadczenia pozapłacowe (np. bony towarowe, dofinansowanie } \\
\text { wypoczynku, bilety na imprezy kulturalne) }\end{array}$ & 41,1 \\
\hline Dogodne godziny pracy (elastyczny czas pracy) & 35,5 \\
\hline $\begin{array}{l}\text { Warunki pracy (wyposażenie stanowiska i dostępność do potrzebnych } \\
\text { zasobów) }\end{array}$ & 33,6 \\
\hline Możliwość samodzielnego działania & 31,1 \\
\hline Jasne kryteria oceny pracy i awansu & 29,4 \\
\hline Organizacja pracy & 23,0 \\
\hline Możliwość samorealizacji w pracy & 22,9 \\
\hline $\begin{array}{l}\text { Uznanie pozafinansowe od przełożonych (pochwała, dyplom, list } \\
\text { gratulacyjny itp.) }\end{array}$ & 20,7 \\
\hline Prestiż stanowiska i miejsca pracy & 16,8 \\
\hline
\end{tabular}

Źródło: opracowanie własne na podstawie wyników przeprowadzonego badania ankietowego.

Wśród wysoko ocenionych czynników (ze zróżnicowanym odsetkiem wskazań) w obydwu grupach znalazły się: gratyfikacje finansowe (nagroda, podwyżka, premia), atmosfera pracy i relacje ze współpracownikami oraz stałość i bezpieczeństwo zatrudnienia, zaś w przypadku nauczycieli akademickich również dogodne godziny pracy. Porównując ze sobą oba zestawienia, można również zauważyć inne zasługujące na uwagę różnice w odpowiedziach, wskazujące m.in. na to, że oferowane przez uczelnię świadczenia pozapłacowe odgrywają znacznie większą rolę $\mathrm{w}$ motywowaniu pracowników niebędących nauczycielami akademickimi (41,1\%) w porównaniu do drugiej analizowanej grupy (jedynie 18,3\% odpowiedzi), natomiast w grupie nauczycieli akademickich ważniejszymi elementami okazały się np. możliwość samorealizacji w pracy czy prestiż zajmowanego stanowiska i miejsca pracy.

Objęci badaniem pracownicy uczelni generalnie pozytywnie ocenili obszar relacji ze swoimi przełożonymi, przy czym lepsze wyniki zostały uzyskane w grupie osób niebędących nauczycielami akademickimi (tabele 3 i 4). 
Tabela 3. Opinie badanych nauczycieli akademickich uzyskane w obszarze „Relacje z przełożonymi”

\begin{tabular}{|l|c|c|c|c|c|}
\hline \multirow{2}{*}{ Wyszczególnienie } & \multicolumn{5}{|c|}{ Odpowiedzi (w \%) } \\
\cline { 2 - 6 } & 1 & 2 & $1+2$ & 3 & 4 \\
\hline Mój przełożony jasno informuje mnie o celach mojej pracy & 36,3 & 42,3 & 78,6 & 15,9 & 5,5 \\
\hline $\begin{array}{l}\text { Mój przełożony udziela mi wsparcia niezbędnego do } \\
\text { efektywnej pracy }\end{array}$ & 30,6 & 40,3 & 70,9 & 21,6 & 7,5 \\
\hline $\begin{array}{l}\text { Mój przełożony zachęca mnie do podejmowania inicjatyw } \\
\text { służących mojemu rozwojowi zawodowemu }\end{array}$ & 30,4 & 43,1 & 73,5 & 19,0 & 7,5 \\
\hline $\begin{array}{l}\text { Mój przełożony udziela mi wsparcia niezbędnego do realizacji } \\
\text { ścieżki kariery i rozwoju zawodowego }\end{array}$ & 28,6 & 37,3 & 65,9 & 24,6 & 9,5 \\
\hline $\begin{array}{l}\text { Mój przełożony zachęca mnie do wykorzystywania własnej } \\
\text { inicjatywy w pracy }\end{array}$ & 31,2 & 41,7 & 72,9 & 19,4 & 7,7 \\
\hline Mój przełożony ceni opinie moje i moich współpracowników & 32,9 & 40,1 & 73,0 & 18,3 & 8,7 \\
\hline $\begin{array}{l}\text { Mój przełożony traktuje wszystkich pracowników } \\
\text { sprawiedliwie }\end{array}$ & 25,4 & 41,3 & 66,7 & 21,4 & 11,9 \\
\hline $\begin{array}{l}\text { Mój przełożony przekazuje mi na bieżąco informację zwrotną } \\
\text { na temat mojej pracy }\end{array}$ & 25,2 & 42,1 & 67,3 & 24,4 & 8,3 \\
\hline Mój przełożony potrafi podejmować dobre decyzje & 26,4 & 52,0 & 78,4 & 16,3 & 5,3 \\
\hline $\begin{array}{l}\text { W mojej pracy mam możliwość zgłaszania przełożonemu } \\
\text { swoich pomysłów, propozycji zmian }\end{array}$ & 43,3 & 43,3 & 86,6 & 10,3 & 3,1 \\
\hline $\begin{array}{l}\text { Zgłaszane przeze mnie opinie i sugestie są brane pod uwagę } \\
\text { przez przełożonych }\end{array}$ & 23,2 & 46,4 & 69,6 & 24,2 & 6,2 \\
\hline $\begin{array}{l}\text { Zawsze, kiedy na to zasługuję, otrzymuję od przełożonego } \\
\text { pochwały za dobrze wykonaną pracę }\end{array}$ & 25,4 & 38,7 & 64,1 & 25,8 & 10,1 \\
\hline $\begin{array}{l}\text { W przypadku problemów zawodowych lub osobistych mogę } \\
\text { liczyć na zrozumienie i pomoc ze strony przełożonych }\end{array}$ & 32,5 & 46,2 & 78,7 & 14,3 & 7,0 \\
\hline $\begin{array}{l}\text { Relacje z przełożonymi mają wpływ na to, że chcę pracować } \\
\text { w UWM w Olsztynie }\end{array}$ & 31,9 & 41,1 & 73,0 & 21,6 & 5,4 \\
\hline
\end{tabular}

Uwaga: 1 - zdecydowanie tak, 2 - raczej tak, 3 - raczej nie, 4 - zdecydowanie nie.

Źródło: opracowanie własne na podstawie wyników przeprowadzonego badania ankietowego.

Tabela 4. Opinie badanych osób niebędących nauczycielami akademickimi uzyskane w obszarze „Relacje z przełożonymi”

\begin{tabular}{|l|c|c|c|c|c|}
\hline \multicolumn{1}{|c|}{ Wyszczególnienie } & \multicolumn{5}{|c|}{ Odpowiedzi (w \%) } \\
\cline { 2 - 7 } & 1 & 2 & $1+2$ & 3 & 4 \\
\hline Mój przełożony jasno informuje mnie o celach mojej pracy & 44,3 & 45,1 & 89,4 & 8,4 & 2,2 \\
\hline $\begin{array}{l}\text { Mój przełożony udziela mi wsparcia niezbędnego do } \\
\text { efektywnej pracy }\end{array}$ & 40,0 & 42,0 & 82 & 14,4 & 3,6 \\
\hline $\begin{array}{l}\text { Mój przełożony zachęca mnie do wykorzystywania własnej } \\
\text { inicjatywy w pracy }\end{array}$ & 38,5 & 41,0 & 79,5 & 15,6 & 4,9 \\
\hline
\end{tabular}




\begin{tabular}{|l|c|c|c|c|c|}
\hline \multirow{2}{*}{ Wyszczególnienie } & \multicolumn{5}{|c|}{ Odpowiedzi (w \%) } \\
\cline { 2 - 6 } & 1 & 2 & $1+2$ & 3 & 4 \\
\hline Mój przełożony ceni opinie moje i moich współpracowników & 33,6 & 49,4 & 83 & 12,5 & 4,5 \\
\hline $\begin{array}{l}\text { Mój przełożony traktuje wszystkich pracowników } \\
\text { sprawiedliwie }\end{array}$ & 28,4 & 45,9 & 74,3 & 16,7 & 9,0 \\
\hline $\begin{array}{l}\text { Mój przełożony przekazuje mi na bieżąco informację zwrotną } \\
\text { na temat mojej pracy }\end{array}$ & 31,5 & 47,0 & 78,5 & 16,8 & 4,7 \\
\hline Mój przełożony potrafi podejmować dobre decyzje & 33,5 & 55,2 & 88,7 & 7,5 & 3,8 \\
\hline $\begin{array}{l}\text { W mojej pracy mam możliwość zgłaszania przełożonemu } \\
\text { swoich pomysłów, propozycji zmian }\end{array}$ & 43,7 & 45,1 & 88,8 & 8,3 & 2,9 \\
\hline $\begin{array}{l}\text { Zgłaszane przeze mnie opinie i sugestie są brane pod uwagę } \\
\text { przez przełożonych }\end{array}$ & 28,3 & 50,4 & 78,7 & 17,3 & 4,0 \\
\hline $\begin{array}{l}\text { Zawsze, kiedy na to zasługuję, otrzymuję od przełożonego } \\
\text { pochwały za dobrze wykonaną pracę }\end{array}$ & 26,2 & 40,8 & 67,0 & 26,3 & 6,7 \\
\hline $\begin{array}{l}\text { W przypadku problemów zawodowych lub osobistych mogę } \\
\text { liczyć na zrozumienie i pomoc ze strony przełożonych }\end{array}$ & 47,8 & 41,2 & 89,0 & 7,5 & 3,5 \\
\hline $\begin{array}{l}\text { Relacje z przełożonymi mają wpływ na to, że chcę pracować } \\
\text { w UWM w Olsztynie }\end{array}$ & 44,1 & 42,3 & 86,4 & 10,8 & 2,8 \\
\hline
\end{tabular}

Uwaga: 1 - zdecydowanie tak, 2 - raczej tak, 3 - raczej nie, 4 - zdecydowanie nie.

Źródło: opracowanie własne na podstawie wyników przeprowadzonego badania ankietowego.

Z badania wynika, że przełożeni jasno informują podległych pracowników, jakie są cele wykonywanej przez nich pracy (NNA - 89,4\% odpowiedzi twierdzących oraz NA - 78,6\%) oraz udzielają im niezbędnego wsparcia (fakt ten potwierdziło $82 \%$ osób niebędących nauczycielami akademickimi i 70,9\% nauczycieli akademickich). Kadra kierownicza zachęca pracowników do wykorzystywania własnej inicjatywy w pracy (NNA - 79,5\% oraz NA - 72,9\%).

Nauczyciele akademiccy potwierdzili przy tym, że przełożeni zachęcają ich do podejmowania inicjatyw służących rozwojowi zawodowemu (73,5\% wskazań), w nieco mniejszym stopniu $(65,9 \%)$ udzielając im jednak wsparcia w rozwoju i realizacji ścieżki kariery.

Zdaniem respondentów, kadra kierownicza Uczelni ceni opinie podległych pracowników (NNA - 83\% odpowiedzi twierdzących oraz NA - 73\%). W zdecydowanej większości wskazali oni również, że mają możliwość zgłaszania kierownictwu swoich pomysłów i propozycji zmian (NNA - 88,8\% oraz $N A-86,6 \%$ ), nieco rzadziej są one zaś brane pod uwagę przez przełożonych (potwierdziło to $78,7 \%$ osób niebędących nauczycielami akademickimi oraz $69,6 \%$ badanych nauczycieli akademickich).

Wyniki badań wskazują, że pracownicy w dużej mierze (NNA $-88,7 \%$ oraz $N A-78,4 \%)$ są przekonani o słuszności decyzji podejmowanych przez swoich 
kierowników. Nieco rzadziej dostrzegają oni sprawiedliwość w traktowaniu przez przełożonych wszystkich podległych pracowników (fakt ten znalazł potwierdzenie w odpowiedziach $74,3 \%$ przedstawicieli grupy $N N A$ oraz $66,7 \%-N A)$. W opinii większości respondentów (NNA - 78,5\% oraz $N A-67,3 \%$ ) przełożony przekazuje na bieżąco informację zwrotną na temat wykonywanej przez nich pracy, natomiast w mniejszym stopniu uważają oni, że zawsze, kiedy na to zasługują, otrzymują od kierownika pochwały za dobrze wykonaną pracę (NNA - 67\% odpowiedzi twierdzących oraz $N A-64,1 \%)$. Natomiast w przypadku problemów zawodowych lub osobistych, według zdecydowanej większości (NNA - 89\% oraz NA - 78,7\%) badanych osób, pracownicy mogą liczyć na zrozumienie i pomoc ze strony przełożonych. W świetle uzyskanych wyników badania, relacje z przełożonymi mają wpływ na to, że respondenci chcą pracować w badanej organizacji (na co wskazuje $86,4 \%$ pracowników niebędących nauczycielami akademickimi i $73 \%$ nauczycieli akademickich).

W wyniku przeprowadzonego badania uzyskano generalnie pozytywny obraz relacji pracowników z przełożonymi w badanej organizacji. Biorąc jednak pod uwagę fakt, iż znaczny odsetek odpowiedzi twierdzących udzielonych przez respondentów w poszczególnych kwestiach poddanych analizie, stanowiły odpowiedzi niezdecydowane („raczej tak”), wydaje się, że zwrócenie przez przełożonych większej uwagi na jakość relacji z podwładnymi mogłoby zwiększyć siłę oddziaływania tego elementu jako istotnego czynnika budowania zaangażowania pracowników, co dotyczy zarówno nauczycieli akademickich, jak i osób zatrudnionych na innych stanowiskach w uczelni.

\section{Podsumowanie}

Temat zaangażowania organizacyjnego oraz zarządzania przez zaangażowanie należy do aktualnych oraz $\mathrm{w}$ wysokim stopniu utylitarnych zagadnień rozpatrywanych na gruncie teorii i praktyki zarządzania. Coraz więcej współczesnych organizacji przyjmuje zasadę, że przewagę nad konkurencją zapewni im wykorzystanie zaangażowania pracowników, przejawiającego się ich zwiększonym wysiłkiem, poświęceniem pracy, wysokim poziomem motywacji wewnętrznej. Stąd pojawia się potrzeba podejmowania działań, które nie tylko powinny się sprowadzać do zewnętrznego motywowania ludzi przy wykorzystaniu bodźców materialnych, lecz także wyzwalających ich wewnętrzne zaangażowanie.

Wyniki badania przeprowadzonego wśród pracowników Uniwersytetu Warmińsko-Mazurskiego w Olsztynie potwierdziły istotne znaczenie relacji z przełożonymi jako jednego z czynników determinujących zaangażowanie 
pracowników. Jakość relacji z przełożonymi znalazła się na stosunkowo wysokim, piątym miejscu w hierarchii ważności czynników motywacyjnych wpływających na poziom zaangażowania, dając pierwszeństwo takim elementom, jak: wysokość otrzymywanego wynagrodzenia oraz gratyfikacje finansowe (podwyżka, nagroda, premia), atmosfera pracy i relacje ze współpracownikami, stałość i bezpieczeństwo zatrudnienia, a w przypadku nauczycieli akademickich również dogodne godziny pracy.

W wyniku przeprowadzonego badania uzyskano generalnie pozytywny obraz relacji pracowników z przełożonymi w badanej organizacji, przy czym jakość tych relacji wyżej oceniły osoby niebędące nauczycielami akademickimi niż osoby zatrudnione na stanowiskach nauczycieli akademickich. Większość respondentów wyraziła opinię, że relacje z kierownictwem pozytywnie wpływają na chęć kontynuacji zatrudnienia $\mathrm{w}$ uczelni. $\mathrm{Z}$ badania wynika, iż objęci nimi pracownicy w dużej mierze mogą liczyć na wsparcie ze strony swoich przełożonych, niezbędne do efektywnej pracy, a w przypadku problemów - także na pomoc i zrozumienie. Przełożeni przekazują pracownikom informacje dotyczące celów wykonywanej przez nich pracy, a także zachęcają do wykorzystania własnej inicjatywy. Nauczyciele akademiccy wskazali przy tym, że kierownictwo zachęca ich do podejmowania inicjatyw służących rozwojowi zawodowemu, rzadziej udzielając im jednak w tym zakresie wsparcia. Zdaniem respondentów, kadra kierownicza Uczelni ceni opinie pracowników, dając im możliwość zgłaszania swoich pomysłów i propozycji zmian, nie zawsze są one jednak brane pod uwagę przez przełożonych. Badani pracownicy w dużej mierze wyrażają przekonanie co do słuszności decyzji podejmowanych przez kierownictwo, w mniejszym stopniu natomiast - co do ich sprawiedliwości w traktowaniu podwładnych. W opinii respondentów, pracownicy dość często mogą liczyć na informację zwrotną od przełożonych na temat wykonywanej przez nich pracy, rzadziej natomiast - na pochwałę w sytuacji, kiedy na to zasługują.

Pomimo uzyskanych w badaniach wielu pozytywnych opinii, można jednak stwierdzić, że w badanej organizacji istnieją pewne rezerwy w dziedzinie budowania zaangażowania organizacyjnego poprzez kształtowanie wysokiej jakości relacji przełożonych z pracownikami. Zwrócenie przez kierownictwo większej uwagi na znaczenie tego czynnika jako istotnej determinanty zaangażowania pracowników mogłoby zwiększyć siłę jego oddziaływania, co dotyczy zarówno grupy nauczycieli akademickich, jak i osób zatrudnionych na innych stanowiskach w uczelni.

Konkludując, na motywację i poziom zaangażowania pracowników wpływa wiele różnorodnych czynników - wiedzę na ich temat warto wykorzystywać dla poprawy jakości i efektywności funkcjonowania organizacji, co dotyczy również funkcjonujących na rynku uczelni wyższych. Strategia budowania zaangażowania 
organizacyjnego powinna być oparta na odpowiednio ukształtowanym, opartym na przejrzystych zasadach i procedurach, systemie zarządzania kapitałem ludzkim, polityce wynagradzania i rozwoju pracowników, efektywnej komunikacji i współpracy oraz wysokiej jakości relacjach międzyludzkich, w tym także na linii przełożony-podwładny.

\section{Bibliografia}

Anitha, J. (2014). Determinants of Engagement and Their Impact on Employee Performance. International Journal of Productivity and Performance Management, 63(3), 308-323.

Armstrong, M. (2009). Zarzq̨dzanie wynagrodzeniami. Kraków: Wolters Kluwer.

Armstrong, M. (2007). Zarzq̨dzanie zasobami ludzkimi. Kraków: Wolters Kluwer.

Borkowska, S. (2014). Rola zaangażowania pracowników. Zarządzanie Zasobami Ludzkimi, 2(97), 9-26.

Bugdol, M. (2006). Wartości organizacyjne. Szkice z teorii organizacji i zarządzania. Kraków: Uniwersytet Jagielloński.

Burkiewicz, M. (2003). Rola zaangażowania pracowników w strategii zarzq̨dzania zasobami ludzkimi. Warszawa: PRET S.A.

Burns, P. (2005). Corporate entrepreneurship. Building an entrepreneurial organization. New York: Palgrave.

Cohen, A. (2007). Commitment Before and After: An Evaluation and Reconceptualization of Organizational Commitment. Human Resource Management Review, 17(3), 336-354.

Croston, D. (2008). Employee Engagement. „The People First” Approach to Building a Business. Sydney: Moonstone Media.

Falcone, P. (2006). Preserving restless top performers: keep your top performers engaged so they don't jump ship once job opportunities arise. HR Magazine, 51(3), 117-122.

Gajdzik, B. (2012). Budowanie zaangażowania pracowniczego w przedsiębiorstwie analiza przypadku. Zarzq̨dzanie Zasobami Ludzkimi, 2, 68-88.

Juchnowicz, M. (2009). Fenomen zaangażowania pracowników. Edukacja Ekonomistów i Menedżerów. Problemy. Innowacje. Projekty, 2(12), 11-23.

Juchnowicz, M. (2012). Zaangażowanie pracowników: sposoby oceny i motywowania. Warszawa: PWE.

Juchnowicz, M. (2010). Zarządzanie przez zaangażowanie. Koncepcje. Kontrowersje. Aplikacje. Warszawa: PWE.

Kahn, W.A. (1990). Psychological Conditions of Personal Engagement and Disengagement at Work. Academy of Management Journal, 33(4), 692-724. 
Kinowska, H. (2009). Wpływ wybranych czynników strukturalnych na zaangażowanie pracowników. Edukacja Ekonomistów i Menedżerów. Problemy. Innowacje. Projekty, 2(12), 65-81.

Kochan, T.A., Dyer, L. (1993). Managing transformational change: The role of human resource professional. International Journal of Human Resource Management, 4(3), 569-590.

Meyer, J.P., Allen, N.J. (1991). A Tree-Component Conceptualization of Organizational Commitment. Human Resource Management Review, 1, 65-69.

Robinson, D., Perryman, S., Hayday, S. (2004). The Drivers of Employee Engagement. Brighton: IES Research Report.

Schaufeli, W.B., Salanova, M., Gonzalez-Roma, V., Bakker, A.B. (2002). The Measurement of Engagement and Burnout: A Two-Sample Confirmatory Factor Analytic Approach. Journal of Happiness Studies, 3, 71-92.

Smythe, J. (2009). CEO - dyrektor do spraw zaangażowania. Kraków: Wolters Kluwer. Spik, A., Klincewicz, K. (2008). Nowe kierunki w zarządzaniu ludźmi - zaangażowanie organizacyjne. W: M. Kostera (red.), Nowe kierunki w zarządzaniu. Warszawa: Wydawnictwa Akademickie i Profesjonalne, 471-492.

\section{Summary}

\section{Quality of Relations with the Superiors as a Factor Determining Employees' Engagement (on the Example of a University)}

In the contemporary conditions, the issue of shaping employees' engagement, which is a key factor in achieving the organization's goals, and simultaneously a determinant of the effectiveness of human capital management, is important from the perspective of any organization, including universities. The identification of the significance of various factors determining its level plays an important role in the process of building employees' engagement. One of such factors is the quality of relations with the direct superiors. The primary goal of the research presented in this study was to identify the importance of the quality of relations with the superiors as one of the factors shaping the engagement of employees of the University of Warmia and Mazury in Olsztyn. The research was carried out using the questionnaire method in the group of academic teachers and people performing other functions.

Keywords: employee engagement, factors shaping employee engagement, relations with the superiors, human capital management 


\section{Dr Sylwia Stachowska}

Doktor nauk ekonomicznych w dyscyplinie nauk o zarządzaniu, zatrudniona na stanowisku adiunkta w Katedrze Organizacji i Zarządzania Wydziału Nauk Ekonomicznych Uniwersytetu Warmińsko-Mazurskiego w Olsztynie. Jest autorką i współautorką kilkudziesięciu publikacji naukowych, w tym podręczników z dziedziny zarządzania, monografii, artykułów w czasopismach specjalistycznych. Jej zainteresowania naukowo-badawcze koncentrują się wokół szeroko pojętej problematyki zarządzania kapitałem ludzkim, ze szczególnym uwzględnieniem problematyki motywowania pracowników i zarządzania wynagrodzeniami, a także nowych trendów w zakresie realizacji funkcji personalnej w organizacjach. Jest konsultantem w zakresie projektowania i wdrażania strategii zarządzania zasobami ludzkimi w przedsiębiorstwach i szkoleniowcem $\mathrm{w}$ dziedzinie kierowania zespołami pracowniczymi. 